\title{
ПРОБЛЕМЫ РЕГУЛИРОВАНИЯ ОБОРОТА ЗЕМЕЛЬ СЕЛЬСКОХОЗЯЙСТВЕННОГО НАЗНАЧЕНИЯ
}

\section{PROBLEMS OF REGULATING THE TURNOVER OF AGRICULTURAL LAND \\ M. Antans}

Summary: Involvement in the turnover of agricultural land in Russia is a problem that needs to be solved. Priority use is given to agricultural land. In practice, a large number of abandoned, unused lands require reclamation, restoration, and additional legal regulation.

The purpose of the study is to consider the problem of turnover of agricultural land, to simplify the legal procedure for returning land to circulation.

Methods of logical and statistical analysis were used in the research. Research result. There is an acute problem of involving agricultural land in the turnover. In Russia, they occupy the second place in terms of area after the land of the forest Fund, the hectares of land that are subject to allocation are unclaimed, despite the fact that the main feature of agricultural land is to ensure food security in Russia, being a means of production in agriculture.

Conclusions. To involve land in the turnover, it is necessary to improve the legal framework. Conduct an analysis of the number of lands not involved in the turnover, the causes and consequences of non-use by regions of Russia. Develop measures aimed at restoring land, identify land plots that are not legally used or used for other purposes.

Keywords: land, law, turnover, agricultural, share, share, problem.

\author{
Антанс Мария Владимировна \\ Аспирант, НОЧУ ВО «Московский финансово- \\ промышленный институт «Синергия»», Москва \\ volhov2019@mail.ru
}

Аннотация: Вовлечение в оборот земель сельскохозяйственного назначения в России является проблемой, требующей решения. Приоритет в использовании имеют сельскохозяйственные угодья. На практике большое количество заброшенных, неиспользуемых земель требуют мелиорации, восстановления и дополнительного правового регулирования.

Целью исследования, является рассмотрение проблемы оборота земель сельскохозяйственного назначения, упрощение правовой процедуры возвращения в оборот угодий.

В процессе исследования использовались методы логического, статистического анализа.

Результаты исследования. Остро стоит проблема вовлечения в оборот земель сельскохозяйственного назначения. В России они занимают второе место по площади после земель лесного фонда, гектары земельных долей, которые подлежат выделу невостребованные несмотря на то, что основная особенность земель сельскохозяйственного назначения обеспечить продовольственную безопасность России, являясь средством производства в сельСКом хозяйстве.

Выводы. Для вовлечения в оборот угодий, необходимо совершенствование правовой базы. Провести анализ по регионам России количества не вовлеченных в оборот угодий, причин и последствий неиспользования. Выработать мероприятия, направленные на восстановление угодий, выявить не законно используемые и используемые не по назначению земельные участки.

Ключевые слова: земля, право, оборот, сельскохозяйственный, пай, доля, проблема.

назначения.

Проблемы в сфере земельных отношений возникли давно, но решить многие так и не удалось в полной мере. Например, возникновение прав на земли сельскохозяйственного назначения. Исходя из судебной практики, только в последнее время юридические лица, которые прошли реорганизацию или стали правопреемниками, в судебном порядке возвращают земельные доли (паи), ранее переданные в уставный капитал колхозов, совхозов, обществ. Доли (паи), предоставленные работникам, были массово выделены в земельные участки, образованные в счет долей в праве долевой собственности. Земельные участки поставлены на государственный кадастровый учет и зарегистрировано право собственности. Большинство из них прошли сделки купли-продажи, и используются не по назначению. Так, в соответствии с Указом Президента Российской Федерации от 27 декабря 1991 года № 323 «О неотложных мерах по осуществлению земельной реформы в РСФСР», Постановлением 
Правительства РФ от 29.12.1991 г. № 86 «О порядке реорганизации колхозов и совхозов» колхозы и совхозы обязаны были до 01.01.1993 г. провести реорганизацию, привести свой статус в соответствие с Законом РСФСР «О предприятиях и предпринимательской деятельности» и перерегистрироваться в соответствующих органах. Члены колхоза и работники совхоза наделялись правом на бесплатный земельный и имущественный пай в общей долевой собственности.

Коллективам совхозов, других сельскохозяйственных предприятий, колхозов и кооперативов, использующих землю на праве бессрочного (постоянного) пользования, до 1 марта 1992 года необходимо было принять решение о переходе к частной, коллективно-договорной и другим формам собственности в соответствии с Земельным кодексом РСФСР (п. 6). Порядок проведения земельной реформы установлен Постановлениями Правительства РФ от 29.12.1991г. № 86«О порядке реорганизации колхозов и совхозов» и от 04.09.1992 г. № 708 «О порядке приватизации и реорганизации предприятий и организаций агропромышленного комплекса». В соответствии с п.10 Постановления Правительства РФ от 29.12.1991г. № 86 «О порядке реорганизации колхозов и совхозов» владелец пая обязан подать заявление во внутрихозяйственную комиссию и указать в нем одну из форм использования пая:

- получение на сумму пая земли и средств производства с целью создания крестьянского хозяйства, частного предприятия по ремонту, строительству, обслуживанию, торговле и других предприятий;

- передача пая в качестве учредительного взноса в товарищество или акционерное общество; передача пая в качестве вступительного взноса в кооператив;

- продажа пая другим работникам хозяйства или хозяйству.

Положением о реорганизации колхозов, совхозов и приватизации государственных сельскохозяйственных предприятий, утверждённым Постановлением Правительства Российской Федерации от 4 сентября 1992 года № 708 «О порядке приватизации и реорганизации предприятий и организаций агропромышленного комплекса», предусматривалось, что в каждом реорганизуемом колхозе и совхозе определяются индивидуальные имущественные паи и земельные доли. С учётом принятого трудовым коллективом реорганизуемого совхоза решения о выборе формы собственности на землю, предусмотренной Земельным кодексом РФ, в районную комиссию по приватизации земель и реорганизации сельскохозяйственных предприятий подавалась заявка на предоставление земли в ту или иную форму собственности, к которой прилагались списки лиц, имеющих право на получение земли в собственность бесплатно в соответствии с Указом Президента Российской Федера- ции от 2 марта 1992 года № 213 «О порядке установления нормы бесплатной передачи земельных участков в собственность граждан», включая пенсионеров этих хозяйств. Пунктом 9 Постановления № 708 от 04.09.1992г. определено, что трудовые коллективы реорганизуемых колхозов, совхозов и приватизируемых государственных сельскохозяйственных предприятий должны принять решение о выборе формы собственности на землю, предусмотренный Земельным Кодексом Российской Федерации.

Согласно п.16 данного Постановления владелец имущественного пая и земельной доли может использовать их следующими способами: - получить при выходе из хозяйства с целью создания крестьянского (фермерского) хозяйства;

- внести в качестве взноса в создаваемое товарищество, акционерное общество или кооператив;

- продать или сдать в аренду другим владельцам долей (паев).

Согласно ст. 11 Закона РСФСР «О предприятиях и предпринимательской деятельности» в редакции 1992 года акционерное общество закрытого типа представляет собой объединение граждан и (или) юридических лиц для совместной хозяйственной деятельности. Уставный фонд акционерного общества образуется только за счет вкладов (акций) учредителей.

В связи с указанными нормами, судами признаются отсутствующими права собственности на земельные участки, образованные в счет земельных долей (пая), исключаются сведений из Единого государственного реестра недвижимости, изымаются земельные участки из чужого незаконного владения. На принятия судебных решений и их исполнение, требуется значительное время, а земли сельскохозяйственного назначения остаются заброшенными, не участвуют в обороте и требуют мероприятий по восстановлению.

На сегодняшний день проходит процедура выдела доли, совершаются сделки с участками, только потом в судебном порядке доли возвращаются в уставный капитал Обществ, земельные участки изымаются из незаконного владения, на основании решения суда их снимают с государственного кадастрового учета и прекращают права. Данный вопрос требует правового регулирования с учетом сложившейся обстановки, на этапе выдела, а не по результату, гектары земель уже выделены в счет долей в праве долевой собственности, проданы и используются не по целевому назначению сельскохозяйственных угодий, разрешенное использование изменено на дачное строительство, участки делят без учета минимальных размеров, установленных для земель сельскохозяйственного назначения, продают и застраивают. 
Необходимо изучить судебную практику по делам, относящимся к выделу земельных долей, ранее внесенных в уставный капитал Обществ. Это поможет принять стратегию для дальнейшего правового регулирования оборота таких долей и остановке дальнейшего выдела, постановке на государственный кадастровый учет, регистрации права собственности не законно образованных земельных участков.

Еще одна проблема требующая внимания, является проведение государственного и муниципального контроля за использованием земель сельскохозяйственного назначения, необходимо систематическое наблюдение за исполнением требований земельного законодательства путем проведения административного обследования земель сельскохозяйственного назначения, выявления не используемых земель, выявления земельных участков используемых не по назначению, проведению анализа правовых актов принятых органами государственной власти и органами местного самоуправления по вопросам использования и охраны земель и земельных участков сельскохозяйственного назначения.

Необходима выработка качественной стратегии вовлечения в оборот земель сельскохозяйственного назначения, совершенствование правовой базы, с учетом полного анализа, статистики отдельно по регионам России, проведение инвентаризации количества не вовлеченных в оборот земель сельскохозяйственного назначения, причин и последствий их неиспользования, выработка мероприятий направленных на восстановление сельскохозяйственных угодий. Выявление земельных участков сельскохозяйственного назначения, занятых сельскохозяйственными угодьями и используемыми правообладателями не по назначению.

Вопрос изменения категории земель сельскохозяйственного назначения и разрешенного использования земельных участков требует особого рассмотрения с принятием и усовершенствованием нормативно правовых актов, регулирующих оборот земель сельскохозяйственного назначения с учетом сложившейся ситуации, более жесткого контроля за изменением категории земель сельскохозяйственного назначения, занятых сельскохозяйственными угодьями, изменением разрешенного использования земель сельскохозяйственного назначения, которое повлечет не возможность использования угодий. Необходимо сохранение целевого использования земельных участков, занятых сельскохозяйственными угодьями.

Проблемой является и вовлечение в оборот заброшенных земель сельскохозяйственного назначения. По статистике гектары земельных долей, которые должны быть выделены, являются невостребованными. Проблема невостребованных долей не решена на протяжении многих лет. Это земли, у которых есть владелец, но он не распорядился своей долей.

В настоящее время принимаются нормативно правовые акты, направленные на решение данной проблемы. Но надо учесть, что необходимо принятие мер, которые позволят достичь не только быстрых результатов. Но смогут вовлечь в оборот неиспользуемые сельскохозяйственные земли с государственной поддержкой мелиорации земель. Без государственной поддержки провести мелиорацию, восстановить угодья сложно. Результат по итогу принятия нововведений и нормативно правовых актов, будет, но земли сельскохозяйственного назначения так и останутся не пригодными к использованию.

В заключении надо отметить, о необходимости индивидуального подхода к проблеме вовлечения в оборот земель сельскохозяйственного назначения с использованием качественной и количественной оценки таких земель, обновленных данных об их состоянии и использовании земель. Требуется принятие в действительно действующей не только в правовом смысле, но и на практике государственной программы, направленной на вовлечение в оборот земель сельскохозяйственного назначения. Принятие и усовершенствование нормативно правовых актов, регулирующих оборот с учетом сложившейся ситуации, статистики и полного анализа.

\section{ЛИТЕРАТУРА}

1. Агроэкологическая оценка земель и оптимизация землепользования / А.Л. Черногоров и др. - М.: Издательство МГУ, 2014. - 272 с.

2. Варламов А.А. Земельный кадастр. В 6 томах. Том 4. Оценка земель / А.А. Варламов. - М.: КолосС, 2016. - 464 с.

3. Мазуров А.В. Комментарий к Федеральному закону « 06 обороне земель сельскохозяйственного назначения» / А.В. Мазуров, В.В. Нахратов, В.Э. Чуркин. - М.: Частное право, 2016. - 304 с.

4. Тихомиров М.Ю. Земельные участки сельскохозяйственного назначения. Предоставление, использование, особенности совершения сделок / М.Ю. Тихомиров. - М.: Издание Тихомирова М.Ю., 2014. - 144 с.

5. Тихомиров М.Ю. Комментарии к Федеральному Закону «0б обороте земель сельскохозяйственного назначения» в новой редакции / М.Ю. Тихомиров. М.: Издание Тихомирова М.Ю., 2014. - 144 с.

(с) Антанс Мария Владимировна (volhov2019@mail.ru).

Журнал «Современная наука: актуальные проблемы теории и практики» 